\title{
What do Ag-Pb isotopes tell us about mining in Lavrion?
}

\author{
MARKOS VAXEVANOPOULOS ${ }^{1}$, JANNE BLICHERT- \\ TOFT $^{1}$, FRANCIS ALBAREDE ${ }^{1}$ AND GILLAN DAVIS ${ }^{2}$ \\ ${ }^{1}$ Ecole Normale Supérieure de Lyon \\ ${ }^{2}$ Department of History and Archaeology, Macquarie University, \\ NSW, Australia
}

Presenting Author: Vaxevanopoulos@gmail.com

Lavrion, one of the most important mining districts of the antique world, contributed to silver flow and coin production in the "polis" of Athens in Greece. The ancient workings comprise numerous mines, shafts, and metallurgical establishments. Different phases of exploitation are dated to the Late NeolithicEarly Bronze Age and the Archaic-Hellenistic Greek and Roman-Byzantine periods. Modern mining reoperated ancient galleries and metallurgical remains from 1864 until 1977. The Ag-rich mineralizations are associated with the intrusion of a Miocene granodiorite in the Plaka area and the presumed existence of non-exposed granitoids. Ancient mining activity in the region was focused on Ag-rich veins, chimneys, and mantos embedded mainly at the contacts of the different rock series in the Kamariza, Ari, Dimoliaki, Soureza, Botsari, Spitharopoussi, and Sounion areas. To shed new light on the isotopic characteristics of the Lavrion ore deposits, we report highprecision $\mathrm{Ag}$ and $\mathrm{Pb}$ isotope compositions of samples from the $\mathrm{Pb}-\mathrm{Zn}-\mathrm{Ag} \pm \mathrm{Au}$ carbonate replacement deposit in the Kamariza district and the intrusion-related polymetallic system in Plaka. Silver in galena resides in submicroscopic pyrargyrite, stephanite, ramdohrite, and Ag-tetrahedrite. Lead isotopic data for metallurgical remains such as slags and litharge are also documented. Galena from the carbonate replacement ore deposit where ancient mining took place has a narrow range of $\varepsilon_{109 \mathrm{Ag}}$ ranging between -0.7 and -0.1 . Galena from the modern mine of Filoni-80 has positive $\varepsilon_{109 \mathrm{Ag}}(+4.6-+9.2)$, while pyrargyrite has negative $\varepsilon_{109 \mathrm{Ag}}(-1.5)$. The Sykia mineralization at south Lavrion has $\varepsilon_{109 \mathrm{Ag}}$ of -3.7 . Galena from the ancient Esperanza mine has $\varepsilon_{109 \mathrm{Ag}}$ ranging from -1.2 to $-0.6 .{ }^{206} \mathrm{~Pb} /{ }^{204} \mathrm{~Pb}$ in galena and cerussite ranges from 18.822 to 18.891 and ${ }^{208} \mathrm{~Pb} /{ }^{204} \mathrm{~Pb}$ from 38.820 to 38.939 . Lavrion metallurgical slags and litharge have $\mathrm{Pb}$ isotope compositions similar to those of the carbonate-hosted mineralizations. In $\varepsilon_{109 \mathrm{Ag}}{ }^{208} \mathrm{~Pb} /{ }^{204} \mathrm{~Pb}$ space coins from Athens [1] are consistent with the isotopic characteristics of the carbonate replacement ores of Lavrion. Despite the scarcity of $\mathrm{Ag}$ isotope data, the isotopic variations of $\mathrm{Ag}$ plotted as a function of either ${ }^{206} \mathrm{~Pb} /{ }^{204} \mathrm{~Pb}$ or ${ }^{208} \mathrm{~Pb} /{ }^{204} \mathrm{~Pb}$ enable better understanding of which silver ores were exploited in the antiquity.

[1] Milot, J. et al., 2021. Chem. Geol. 564, 120028. 